\title{
KONSEPSI MAHRAM SEBAB PERZINAAN DALAM HUKUM ISLAM
}

\author{
Moch. Nurcholis \\ Institut Agama Islam Bani Fattah Jombang, Indonesia \\ moch.nurcholis@,iaibafa.ac.id
}

\begin{abstract}
Jurisprudence books divide the concept of marriage into two groups, First, the group that is permissible for marriage. Second, the group that is not allowed or forbidden to be married (mahram). The concept is based on the presence or absence of blood relations between the bride and groom. So in the fiqh study mahram is divided into three in general namely mahram bi nasab, mahram bi musaharah and mah ram bi roudlo'. However, there is a relationship where the scholars disagree, namely whether a male adulterer has an affair with a daughter resulting from adultery ?. This is interesting to study considering that both figh books and laws in Indonesia have stated that children born outside a legal marriage (both adultery and siri) only have a nasab relationship (mahram) with the mother and family of the mother. To answer the problem of whether a male adulterer has a relationship with a daughter of adultery and may or may not get married, the writer will examine the criteria of mahram contained in the books of fiqh. After obtaining data about the forms of security, it is then analyzed using the legal excavation method in the form of qiyas. In the qiyas methodology there are stages to finding illat law. The technique of determining illat can be done by using two common methods, namely using the theorem naqli and' aqli.
\end{abstract}


So that the 'illat law emerges 'illat similarity between cells of genetic material contained in sperm and milk so as to make both of them a major influence on the mental and physical health of a child born or breastfed that is inherited from the genetic cells of his parents. From these findings, it can be concluded that the marriage between biological father and daughter resulting from adultery is prohibited.

Keyword: Mahram, Qiyas, Adultery Child

\section{Pendahuluan}

Selama ini konsepsi tentang larangan menikahi perempuan banyak dikenal dengan istilah mahram. Dalam perkembangannya konsepsi mahram terbagi menjadi dua jenis, mahram muabad (haram selamanya) dan mahram muaqqat (haram temporal). ${ }^{1}$ Islam menjadikan perkawinan sebagai jalan keluar bagi setiap orang untuk melestarikan keturunanya. Berkenaan dengan itu Allah membuat suatu ketentuan dimana terdapat wanita yang khusus untuk dilarang menikahinya. Al-Qur'an surat al-Nisā' ayat 23:

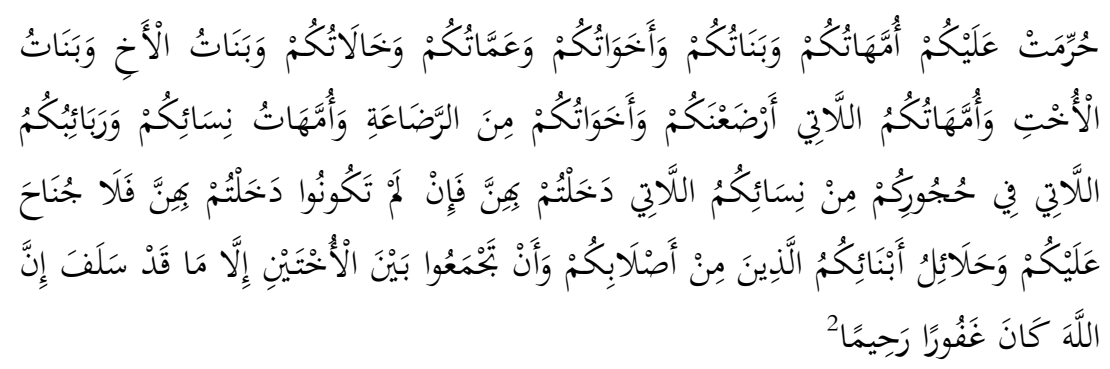

Ulama fikih, berdasakan ketentuan dalam al-Qur'an al-Nisa' ayat 23 dan hadis-hadis Nabi merumuskan tentang sebab-sebab terjadinya status mahram dalam perkawinan, yakni sebab pertalian nasab, hubungan perkawinan (mushaharab), dan sebab persusuan (al-radla).

Keabsahan pernikahan baik dalam fikih klasik maupun dalam peraturan perundang-undangan yang berlaku di Indonesia erat kaitannya dengan istilah nasab dan mahram. Nasab adalah istilah yang menggambarkan proses bercampurnya sperma laki-laki dan ovum wanita

\footnotetext{
${ }^{1}$ Amir Syarifuddin, Hukum Perkawinan Islam di Indonesia (Jakarta: Prenadamedia Group, 2011), 109.

2 Al-Qur'an, 4: 23.
} 
atas ketentuan syariat, apabila percampuran tersebut berdasarkan maksiat maka hal itu tidak lebih dari sekedar reproduksi biasa dan bukan termasuk nasab yang benar sehingga tidak termasuk dari ayat tabrim.

Nasab implikasi hukumnya lebih pada hal yang bersifat keperdataan seperti nafkah, wali, dan waris. Sedangkan mahram lebih pada legalitas perkawinan, tidak membahas tentang keperdataan. Mahram atau yang biasa disebut dengan istilah muhrim di Indonesia berasal dari kata harama yang artinya mencegah bentuk mașdar dari kata ḥarama yang artinya yang diharamkan atau dilarang. Dengan demikian, maka mahram secara istilah adalah orang yang haram, dilarang atau dicegah untuk dinikahi. ${ }^{3}$

Di Indonesia dalam Kompilasi Hukum Islam dan UU Perkawinan Nomor. 1 tahun 1974 memang telah dicantumkan aturan terkait perempuan yang dilarang untuk dinikahi seperti yang telah dijelaskan dalam al-Qur'an. Akan tetapi kemudian muncul sebuah problematika hukum dimana ketika seorang ayah biologis menikahi yang dilahirkan oleh wanita yang dibuahi di luar perkawinan?

Makna di luar perkawinan sendiri dapat dibagi menjadi dua bagian yaitu Pertama, Perkawinan yang sah menurut agama namun tidak sah menurut Undang-undang, seperti nikah siri. Kedua, Perkawinan yang disebabkan oleh faktor hamil dahulu sebelum akad (zina). Dalam penelitian ilmiah ini penulis lebih fokus terhadap makna kedua dari pengertian di luar perkawinan.

Dalam hukum Islam, setiap anak terlahir dalam kondisi suci dan tidak membawa dosa turunan, sekalipun ia terlahir sebagai hasil zina. Namun dalam realitas di masyarakat anak hasil zina seringkali terlantar karena laki-laki yang menyebabkan kelahirannya tidak bertanggung jawab untuk memenuhi kebutuhan dasarnya, serta seringkali anak dianggap sebagai anak haram dan terdiskriminasi karena dalam akte kelahiran hanya dinisbatkan kepada ibu. ${ }^{4}$

Persetubuhan antara seorang laki-laki sebagai ayah biologis dengan perempuan yang kemudian menghasilkan seorang anak perempuan dari hubungan diluar perkawinan atau zina. sedangkan hukum pezina laki-laki mengkahi anak perempuan hasil hubungan di luar perkawinan atau zina, mayoritas Ulama' khususnya Shafi'iyyah menjelaskan bahwa praktek perkawinan sebagaimana diatas diperbolehkan karena tidak adanya hubungan nasab diantara keduanya. Hal tersebut didasarkan kepada

\footnotetext{
3 Qomarudin Sholeh, Ayat-Ayat Larangan Dan Perintah, (Bandung: CV Diponegoro, 2002), 146.

${ }^{4}$ Lihat UU No. 1 Tahun 1974 Pasal 43 ayat 1 dan Kompilasi Hukum Islam (KHI) pasal 100.
} 
pembagian mạ̣ram, menurut Shafi'iyyah konsep mạ̣ram disebabkan beberapa alasan ada kalanya sebab hubungan perkawinan yang sah, (mahram bi nasab), mahram sebab hubungan sepersusuan (mahram bi roudla) dan mạ̣ram sebab hubungan mertua (maḩram bi musaharah). Oleh karenanya seorang anak yang tidak termasuk dalam bagian-bagian diatas maka boleh di nikah sebab tidak adanya konsep mahram, sama halnya anak yang lahir di luar nikah.

\section{Metode Penelitian}

Pendekatan yang digunakan dalam penelitian ini adalah pendekatan perundang-undangan (statute approach). Statute approach adalah pendekatan dengan menggunakan legislasi dan regulasi. Kecuali penelitian dalam ruang lingkup hukum adat, penelitian hukum dalam level dogmatik hukum tidak dapat melepaskan diri dari pendekatan perundang-undangan (peraturan tertulis yang dibentuk oleh lembaga negara atau pejabat yang berwenang dan mengikat secara umum). Dalam pendekatan jenis ini, peneliti akan mencari peraturan perundang-undangan yang berkaitan dengan isu yang diteliti. ${ }^{5}$

Jenis penelitian ini apabila ditinjau fokus kajiannya, termasuk penelitian hukum normatif. ${ }^{6}$ Sedangkan apabila ditinjau dari sisi operasional pengumpulan data, tergolong studi kepustakaan (library research). ${ }^{7}$ Mengingat fokus kajian dan operasional yang digunakan, maka paradigma dalam penelitian ini termasuk paradigm kualitatif dengan menggunakan alur berfikir dan pola kerja induktif- deduktif.

Sumber data primer yang digunakan dalam penelitian ini adalah, kitab al-Mabsut, karya Shamsuddin al-Sarkhasi Usül al-Fiqh alIslamīy karya Wahbah al-Zuhayli dan Undang-undang perkawinan tabun 1974 serta Kompilasi Hukum Islam. Sedangkan sumber data sekunder adalah literatur yang berkaitan dengan permasalahan mahram dalam perkawinan, baik berupa jurnal, buku, dan kitab fikih dan ushul fikih karya ulama.

Dalam pengumpulan data, penelitian ini menggunakan metode kepustakaan, yakni pengumpulan data dengan bantuan bermacam-

\footnotetext{
${ }^{5}$ Peter Mahmud Marzuki. Penelitian Hukum. Jakarta: Kencana, 2010. 97 \& 194.

${ }^{6}$ Penelitian hukum normatif adalah penelitian hukum yang mengkaji hukum tertulis dari berbagai aspek. Soerjono Soekanto. Pengantar Penelitian Hukum. Jakarta: UI-Perss, 2008. 51.

${ }^{7}$ Library research adalah penelitian yang menjadikan bahan pustaka sebagai bahan utama dalam proses penelitian. Hasjim Abbas. Metodologi Penelitian Hukum Islam. Jombang: Program Pascasarjana Studi Hukum Islam Universitas Darul 'Ulum. 2010. 11.
} 
macam materi yang ada di perpustakaan. Pengumpulan data diawali dengan mencari teori-teori yang berhubungan dengan pembahasan yang diambil dari kepustakaan, kemudian ditelaah dan dikaji, sehingga menjadi data yang dibutuhkan untuk penyelesaian penelitian. ${ }^{8}$ Untuk menganalis data yang telah terkumpul, agar hasil penelitian sesuai dengan rumusan yang telah ditetapkan, dalam penelitian ini teknik analisis yang digunakan adalah analisis isi (content analysis) melalui metode deskriptif analitik.

\section{Konsepsi Mahram Sebab Perzinaan Dalam Hukum Islam}

Mahram atau yang biasa disebut dengan istilah muhrim di Indonesia berasal dari kata harama yang artinya mencegah bentuk masdar dari kata harama yang artinya yang diharamkan atau dilarang. Dengan demikian, maka mahram secara istilah adalah orang yang haram, dilarang atau dicegah untuk dinikahi. ${ }^{9}$

Imām Ibn Qudamah menyatakan, mahram adalah semua orang yang haram untuk dinikahi selama-lamanya karena sebab nasab, persusuan dan pernikahan. ${ }^{10}$

Abū al-Ḥasan 'Aliy al-Ḥusain Ibn Muhammad al-Shaghdi menjelaskan mạ̣ram dibagi menjadi dua bagian besar yakni mạ̣ram mu'abbad dan mạ̣ram muwaqat. ${ }^{11}$ Adapun mahram mu'abbad dibagi menjadi dua bagian yakni:

\section{Mahram bi nasab}

Mahram bi nasab dibagi menjadi empat bagian yakni: a) Ibu sampai jalur ke atas, b) Anak sampai jalur ke bawah, c) Saudara dari ayah atau ibu, d) Saudara keponakan.

Pembagian ini sebagaimana yang telah dijelaskan dalam al-Qur'an Ayat 23 surat al-Nisā':

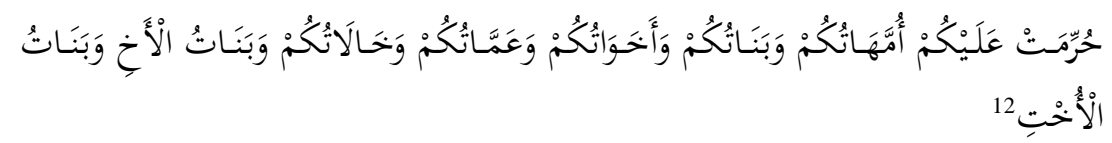

\section{Maḥram bi sabab}

\footnotetext{
${ }^{8}$ Mardalis. Metode Penelitian, (Jakarta: Bumi Aksara,2002), 28.

9 Qomarudin Sholeh, Ayat-Ayat Larangan Dan Perintah, (Bandung: CV Diponegoro, 2002), 146.

${ }^{10}$ Ibn Qudamah, al-Mughniy Juz. VII (Beirut: Dar al Kitab al Arabiy, t.th), 470.

11 Abū al-Hasan 'Aliy al-Husain Ibn Muhammad al-Shaghdi, al-Nitfi $\overline{f i}$ al-Fatâway Juz II (Beirut: muassasah al-risalah, t.th), 852.

12 Al-Qur'an, 4: 24.
} 
Mahram bi sabab dibagi menjadi sepuluh bagian yakni:

a) Al-rauda' (sepersusuan).

Rada'ah secara bahasa adalah proses menyedot puting, baik hewan maupun manusia. Sedangkan menurut shara' yaitu dengan sampainya air susu manusia pada lambung anak kecil yang belum genap berumur dua tahun. ${ }^{13}$ Ulama' fiqh mengatakan bahwa terdapat pengaruh dalam hal fisik dan psikologis terhadap anak yang umurnya kurang dari dua tahun kemudian disusui oleh seorang ibu. ${ }^{14}$

Ayat yang menyebutkan tentang mahram saudara susuan adalah ayat 233 Surat al-Baqarah:

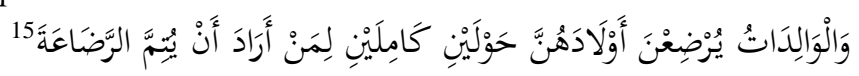

Dan ayat 23 surat al-Nisā':

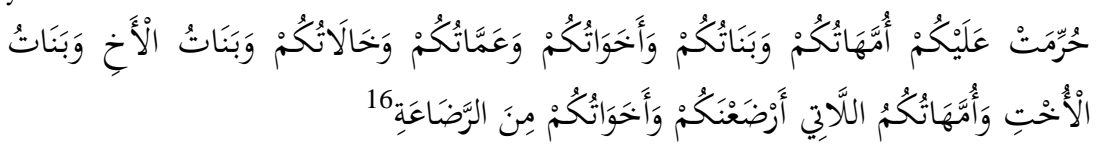

Berdasarkan sepakat ulama' selain Abū Hanifah rukun radā'ah adalah: 1) Anak yang menyusu, 2) Wanita yang menyusui menurut beberapa pendapat para ulama disyaratkan adalah seorang wanita, baik dewasa, dalam keadaan haid, hamil atau tidak. Akan tetapi ulama berbeda pendapat tentang air susu dari wanita yang sudah meninggal. ${ }^{17}$ Menurut Imām Shafi'i susu harus berasal dari wanita yang masih hidup, sedangkan menurut Imam Hanafi dan Malik boleh meskipun tersebut sudah mati. ${ }^{18}$, 3) Air susu, Menurut jumhur 'ulama syarat radā'ah yang dapat mengharamkan nikah. ${ }^{19}$

b) Al-musaharah (mertua),

c) Al-Mut'ah (nikah kontrak),

d) Al-Zināal-Sarìh,

e) Jima' sebab perkawinan yang sah,

f) Jima' sebab perkawinan yang fasid,

g) Jima' sebab nikah subhat,

\footnotetext{
13 'Abd al-Rahmman al-Jaziri., Kitab al-Fiqh 'Alā al-Madžbab al-Arba'ah Juz IV, (Beirut: Dār al-Fikr. t.th), 219.

14 Abdul Aziz Dahlan, Ensiklopedi Hukum Islam ( Jakarta: Ichtiar Baru Van Hoeve, 1997), 1475.

15 Al-Qur'an, 2: 233.

16 Al-Qur'an, 4: 23.

${ }^{17}$ Ibn Rushd, Bidāyah al-Mujtahìd Juz II (Beirut: Dār al-Kutub al-'Ilmiyyah, 1988), 39.

18 'Abd al-Rahman al-Jaziri., Kitab al-Figh., 221.

${ }^{19}$ Waḥbah Zuhailiy, al-Fiqh al-Islām wa 'Adillatubu (Beirut: Dār al-Fikr, 2017), 72.
} 
h) Jima' sebab kepemilikan yang sah,

i) Jima' sebab kepemilikan yang fasid,

j) Jima' sebab kepemilikan yang subhat

Sedangkan mạ̣ram muwaqqat terbagi menjadi sepuluh bagian yakni sebagai berikut:

a) Wanita yang ditalak tiga oleh suaminya

b) Seluruh kerabat yang mempunyai hubungan mahram sebab nasab, sepersususan dan mertua

c) Pernikahan budak perempuan dengan laki-laki merdeka

d) Pernikahan lebih dari empat wanita

e) Wanita Iddah

f) Wanita Kafir

g) Wanita Murtad

h) Wanita yang menjadi rampasan perang

i) Wanita hamil sebab zina

j) Perzinaan

Dari klasifikasi yang dipaparkan oleh Abū al-Ḥasan 'Aliy terkait pembagian mahram diatas terdapat satu bagian berupa status larangan menikahi wanita hamil sebab zina, hal ini menjadikan alasan khusus juga untuk menghukumi haram menikahi anak yang lahir sebab zina dikarenakan antara laki-laki dan anak hasil zina tersebut masih mempunyai hubungan mahram. Alasan normatif dimaksudkan merujuk pada ketentuan hadis, yaitu terkait dengan ketetapan Rasulullah mengenai orang-orang yang berzina pada zaman Jahiliah, Rasul menetapkan kekerabatan mahram anak dengan mereka-mereka yang melakukan zina sedangkan warisan tidak ditetapkan Hal ini nampaknya mengacu pada dali hadis di bawah ini:

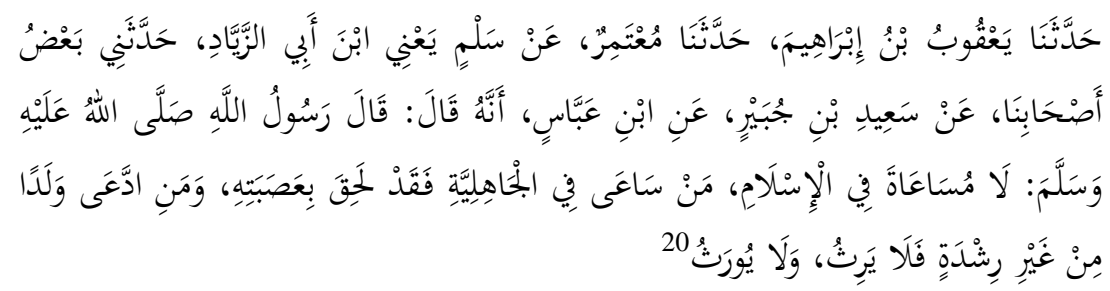

Telab menceritakan kepada kami Ya'qüb Ibn Ibrähim, menceritakan

kepada kami Mu'tamir dari Salim yakni Ibn Abi al-Ziyyäd, menceritakan kepada kami sebagian dari sahabat kami dari Sa'ìd

${ }^{20}$ Abi Dāwud, Sunan Abī dawnd Juz III (t.t: t.p, t.th), 90. 
Ibn Jubair dari Ibn 'Abbās dia berkata babwa Rasulullah bersabda "Tidake ada pelacuran dalam Islam, barang siapa yang telab ber₹ina pada masa jahiliyah maka ia telah mendapatkan bagiannya. Barang siapa yang mengklaim seorang anak. bukan dari pernikahan yang sah maka ia tidak mewarisi dan tidak diwarisi."

Hadis di atas mengacu pada dua hal sekaligus, artinya anak tetap memiliki mahram kepada kedua orang tuanya, sehingga orang tuanya mendapatkan unsur kemahraman tersebut. Di sisi lain, justru antara anak dengan ayahnya yang berzina tidak saling mewarisi, meskipun didahului dengan adanya pengakuan. Berbeda halnya dengan ketetapan keperdataan anak, misalnya warisan anak bisa terputus ketika ia diketahui telah membunuh atau keluar dari agama Islam (murtad), termasuk juga penghalang warisan adalah karena hubungan zina.

\section{Aplikasi Qiyas dalam Larangan Perkawinan Anak Hasil Zina dengan Ayah Biologisnya.}

Sebagaimana yang menjadi rukun dari metodologi qiyas harus ada 'illat hukum yang menjadi alasan pokok diperbolehkannya furu' diqiyaskan kepada aṣl. Kemudian dalam pembahasan selanjutnya dalam qiyas terdapat unsur-unsur pokok yang harus dipenuhi. Jika rukun-rukun tersebut tidak dapat terpenuhi maka secara otomatis qiyas juga tidak dapat diterapkan. Secara garis besar qiyas dibagi menjadi empat yakni al'Asl atau al-maqisu 'alaih, al-far'u atau maqiisu, bukum al-asl atau bukum li alasl 'alaih, dan 'illat al-bukmu. ${ }^{21}$ berikut:

Rukun-rukun qiyas tersebut dalam pemaparannya adalah sebagai

1. Al-'Asl atau al-maqīsu 'alaib

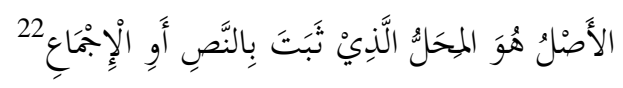

Asl adalah sesuatu yang bukumnya ditetapkan oleh nash atau ijma'.

Aṣl dalam penjelasan detailnya adalah tempat rujukan hukum yang dijadikan dalam penyerupaan atau penyamaan íllat dengan cabang atau

21 Waḥbah Zuhailìy, Ușūl al-Fiqh al-Islämiy, 576.
22 Ibid, 576. 
al-far'u. ${ }^{23}$ Oleh karenanya Asl sering disebut dengan musyabbah bih atau yang diserupai, al-maqisu 'alaih adalah tempat mengqiyaskan.

Assl dalam kajian ilmiah penelitian ini yakni air susu saudara sepersusuan (roudlo') yang kemudian dijadikan tempat pengqiyasan atau sesuatu yang diserupai dengan ketentuan dasar bahwa as l harus mempunyai dalil yang jelas baik dari dalil naqli (al-qur'an dan hadis) atau 'aqli (ijma' ulama').

2. Al-far'u atau maqisu

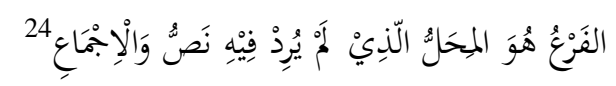

Al-far'u adalah sesuatu yang bukumnya tidak terdapat dalam nash dan ijma'.

Al-far'u adalah sesuatu yang hukumnya tidak terdapat dalam nash dan ijma'. ${ }^{25}$ Furu' menjadi sesuatu yang diqiyaskan, dalam kajian ilmiah penelitian ini penulis menyebut air sperma sebab hubungan perzinaan sebagai furu'. Yakni air sperma sebab hubungan perzinaan diqiyaskan dengan air susu saudara sepersusuan. Pada dasarnya air sperma sebab hubungan perzinaan ini menjadi perbedaaan pendapat dikalangan ulama' khususnya dalam kalangan ulama' hanafiyyah dan ulama' shafi'iyyah.

3. Hukum al-asl atau bukum li al-asl 'alaih

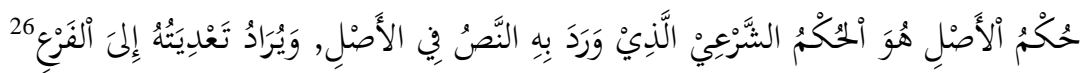

Hukum Asl adalah bukum syara' yang terdapat nashnya yang ditetapkan pada asl dan dipakai sebagai hukum bagi al far'u.

Sebagaimana yang telah dipaparkan dalam sub sub bab asl bahwa air susu saudara sepersusuan yang menjadi tempat pengqiyasan. Pengambilan dalil dari hukum mahram saudara sepersusuan adalah ayat 23 surat al-Nisā':

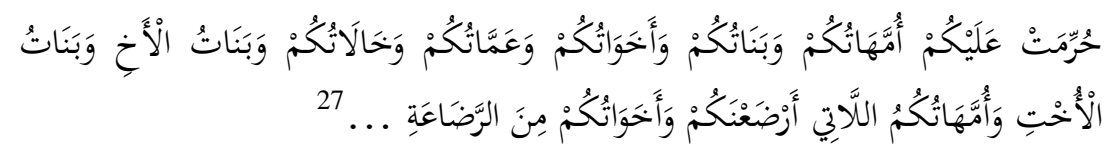

${ }^{23}$ Abì Yahya., Gāyah al-Wuṣūl (Lebanon: Dār al-Kotob al-Ilmiyah, t.th), H. 285.

24 Wahbah Zuhailiy, Ușül al-Fiqh al-Islamiy, 577.

25 Ibid, 577.

${ }^{26} \mathrm{Ibid}, 577$. 


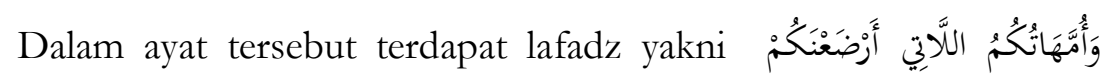
وَاََخَوَاتُكُمْم مِنَ الرَّضَاعَةِ yang kemudian mengindikasikan bahwa terdapat hubungan mahram antara seorang ibu yang menyusui dan anak yang disusui begitu juga meliputi saudara sepersusuan. Selanjutnya dalam kajian fikih sering disebut dengan istilah mahram bi roudlo'. Oleh karena mendasar pada dalil yang terdapat didalam nash al-qur'an yang disebutkan sebagaimana diatas maka hukum asal dari roudlo' adalah mahram.

4. Tllat al-bukmu

Tllat adalah sifat yang dibangun oleh hukum asl

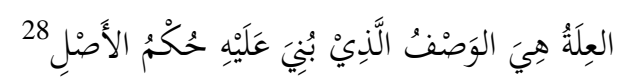

'Illat hukum dalam pemahaman yang mudah adalah titik temu persamaan antara așl dan furu' baik dalam dari segi eksistensinya yakni jenis materinya atau dari segi sifat-sifat yang melekat dalam materi tersebut. Dari titik temu inilah nantinya menimbulkan hukum baru untuk furu' atau dalam hal ini adalah air sperma sebab hubungan perzinaan.

Dalam fikih empat madhzab disebutkan bahwa seorang pria pezina dihalalkan menikahi wanita hasil dari Perzinaannya. Lebih detilnya bahwa Diperbolehkan bagi seorang pria menikahi anak wanitanya yang tercipta dari air maninya hasil zina, jikalau berzina dengan wanita hasil zina dan lalu wanita yang dizinahinya tersebut hamil lalu didapati keterangan bahwa wanita yang dizinaihinya tersebut ternyata anak hasil zina dengan ibu wanita tersebut, maka tidaklah diharamkan kepadanya disebabkan air mani hasil perbuatan zina tidak memiliki kehormatan baginya yang disebabkan kebenciannya pada halalnya pernikahan. ${ }^{29}$

Akan tetapi Ulama' Hanafiyyah yakni Al-Imām Fakhruddin Uthmān Ibn 'Ali al-Zayla'i mengemukakan pendapatnya yang berbeda yaitu bahwa anak hasil zina tetap menjadi mahram bagi pezina laki-laki jika memang benar-benar diyakini bahwa anak hasil zina tersebut merupakan benih sperma dari pezina laki-laki. Berikut redaksi yang dikemukakan oleh beliau dalam kitab Hāshiyah al-Shilbìy:

\footnotetext{
27 Al-Qur'an, 4: 23.

${ }^{28}$ Waḥbah Zuhailìy, Ușūl al-Fiqh al-Islämiy, 578.

${ }^{29}$ Abdurrohman bin Muhammad Audhi Al Jaziri, kitab al-fiqhu 'ala madzahab al-arba'ah Juz II (Bayrut: Darul Fikr, 1990), 1424.
} 


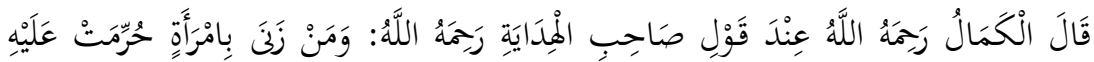

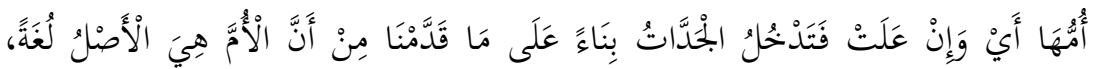

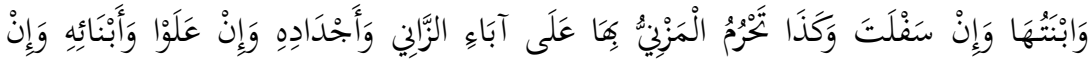

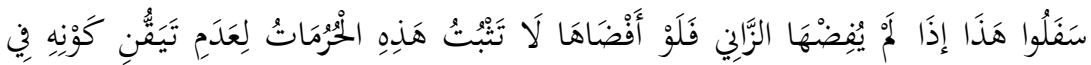

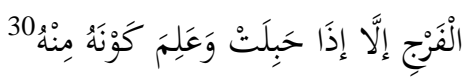
Al-kamal menukil dari pengarang kitab al-hidayah berkata: "Barang siapa zina dengan seorang perempuan maka haram baginya ibu perempuan tersebut yakni sampai keturunan keatas termasuk nenek dan seterusnya dikarenakan arti al-üm menurut bahasa adalab pokok, begitu juga (haram) terbadap anak dari perempuan tersebut sampai keturunan kebawah, haram pula bagi ayah laki-laki (kakeke) sampai keturunan keatas dan anak laki-laki sampai keturunan kebawah, hal demikian dibukumi mahram apabila laki-laki tersebut tidak sampai membedah keperawanan perempuan jika sampai keperawanan wanita terbedah maka ttidak menjadikan mabram kecuali sampai mengandung anak yang telah diyakini dari benih lakilaki tersebut.

Pendapat tersebut dikemukakan oleh beliau dengan alasan 'illat lahirnya anak adalah sebab jima' sedangkan penetapan mahram adalah sebab menyentuh perempuan, ringkasnya tidak ada aktifitas jima' tanpa menyentuh. Lebih lanjut alasan tersebut diperkuat dengan adanya satu hadis berikut:

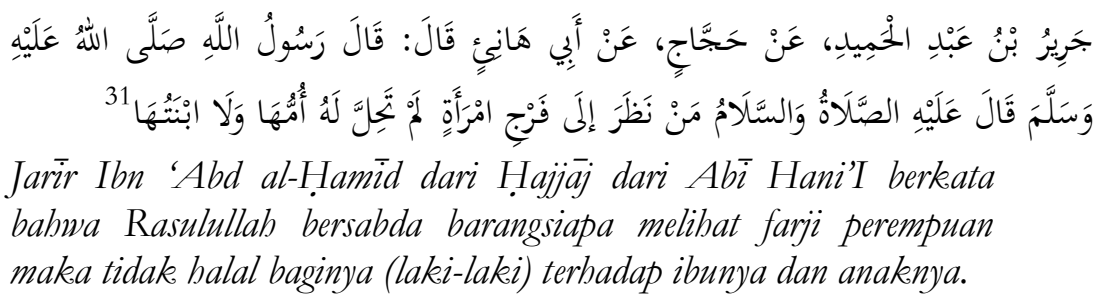

Hadis tersebut menerangkan begitu jelas terkait konsekuensi dari melihat farji. Kemudian hadis tersebut digunakan dasar penetapan maḥram bagi laki-laki dan anak hasil zina dengan alasan melihat saja

\footnotetext{
30 Al-Imām Fakhruddin Uthmān Ibn 'Ali al-Zayla'i, Tabyīn al-Haqäiq Sharb Kanz alDaqāiq Juz II (Mesir: Matba’ah al-Kubra, t.th), 107.

31 Abū Bakr 'Abdullah Ibn Muḥammad Ibn Abi Shaibah, al-Musannaf Ibn Abī Shaibah (Beirut: Dār Qurtubah, 2006), 480.
} 
sudah menjadikan hukum maḥram apalagi dengan menyentuh bahkan menyetubuhinya.

Dalam metodologi qiyas tidaklah cukup hanya mengetahui adanya 'illat yang terdapat dalam asl atau far'u, tetapi juga harus mengetahui dalil-dalil yang menunjukkan 'illat tersebut baik dari nash, ijma' ataupun istinbat (penelitian). Ketentuan hukum baik yang terdapat di dalam alQur'an ataupun yang terdapat di dalam hadis tidak ditetapkan begitu saja tanpa mempunyai alasan rasional/logis yang dijadikan sebuah landasan hukum, hal ini sesuai dengan satu kaidah fikih.

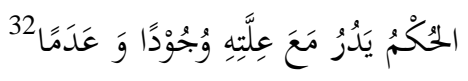

Hukum itu berlaku terhadap ada dan tidaknya 'illat.

Adapun tahapan-tahapan tersebut adalah:

\section{Al-Sabru wa Al-Taqsim}

Al-sabru adalah observasi seorang mujtahid untuk menentukan satu dari sekian banyak sifat yang terkandung dalam asl yang berhasil diinventarisir, dengan cara membuang semua sifat yang dinilai tidak layak dijadikan 'illat dengan berpedoman pada dalil-dalil yang bisa menguatkannya. ${ }^{33}$

Dalam tahapan ini penulis akan memaparkan seluruh kesamaan antara air susu roudlo' dan air sperma perzinaan. Kemudian selanjutnya ada metode sweeping atau pembersihan terhadap sifat-sifat yang dinilai tidak relevan sebagai 'illat hukum. Adapun kesamaan yang mencolok dari air susu roudlo' dan air sperma perzinaan adalah sebagai berikut:

\begin{tabular}{|c|l|c|c|}
\hline No & Unsur Pembanding & Air susu & Air Sperma \\
\hline \hline 1 & Jenis & Cair \\
\hline 2 & Warna & Putih \\
\hline 3 & Tempat Keluar & $\begin{array}{r}\text { Mengandung sel genetik dan sistem } \\
\text { kekebalan tubuh antibody }\end{array}$ \\
\hline 4 & Unsur-unsur & $\begin{array}{r}\text { Mempengaruhi kesehatan fisik dan } \\
\text { mental anak }\end{array}$ \\
\hline 5 & Efek terhadap anak & $\begin{array}{r}\text { Berasal dari hubungan tanpa akad } \\
\text { perkawinan yang sah }\end{array}$ \\
\hline 6 & Asal hubungan & \\
\hline
\end{tabular}

\section{Tanqīh al-Manat}

32 'Abd al-Ażiz Muḥammad 'Azzām, al-Qawāid al-Fiqhiyyah (Mesir: Dār al-Hadith, 2005), 222.

33 Abì Yahyā Zakariā, Gāyah al-Wuṣūl Syarh Lubb al-'Uṣūl, 400 
Dalam tahapan ini sebenarnya sama seperti tahapan sebelumnya yakni mencari sifat-sifat yang menjadi persamaan antara air susu roudlo' dan air sperma perzinaan kemudia disaring dari sekian sifat yang sangat relevan untuk dijadikan sebagai 'illat hukum. Namun dalam tahapan ini lebih ketat yakni diambil dua sifat persamaan dari seluruh sifat yang dianggap sama. ${ }^{34}$ Dua sifat yang sangat mencolok antara air susu roudlo' dan air sperma perzinaan adalah Pertama, pengaruh dari unsur yang membangun keduanya (air susu dan air sperma) yakni sel genetik. Adalah sama-sama mempengaruhi terhadap kesehatan fisik dan mental anak. Kedua, Antara air susu dan air mani sama-sama dihasilkan dari hubungan tanpa akad perkawinan yang sah. Anak yang dihasilkan dari hubungan mahram roudlo' tidak diawali dengan perkawinan yang sah begitu juga anak yang dihasilkan dari hubungan perzinaan yang disebabkan adanya persetubuhan tanpa ikatan akad perkawinan yang sah terlebih dahulu.

\section{Tahqiq al-Manat}

Tahapan ini merupakan tahapan terahir dari teknik penentuan 'illat metodologi qiyas. Dalam tahapan ini menyaring satu illat hukum dari dua 'illat yang telah disaring dalam tahapan Tanqīh al-Manat. ${ }^{35}$ Adapun satu 'illat yang cocok dijadikan sebagai 'illat hukum adalah pengaruh dari unsur yang membangun keduanya yakni sel genetik, yakni sama-sama mempengaruhi terhadap kesehatan fisik dan mental anak.

Salah serang peneliti Dr. Jamaludin Ibrahim, seorang professor toksikolog di University of California dan direktur laboratorium penelitian hidup di Amerika Serikat, menyatakan bahwa dalam penelitian terhadap sistem kekebalan tubuh perempuan, terungkap bahwa ASI terdiri dari sel-sel yang membawa sifat genetik campuran dari ayah dan ibu. Dan secara otomatis sifat-sifat ini akan berpindah ke anak yang disusui oleh ibunya. Oleh karena itu anak akan memiliki kemiripankemiripan dengan saudara-saudaranya dalam hal sifat maupun fisik. ${ }^{36}$

\section{Penutup}

Dari pemaparan di atas dapat dipahami bahwa pernikahan antara anak hasil zina dengan ayah biologisnya merupakan sesuatu yang dilarang karena dua sebab. Pertama, bahwa seseorang yang zina dengan perempuan maka kerabat perempuan keatas (ibu dan seterusnya) begitu juga keturunan kebawah (anak dan seterusnya) menjadi mahram. Kedua,

\footnotetext{
${ }^{34}$ Ibid, 400

${ }^{35}$ Ibid, 400

36 Abdul Syukur Al-Azizi, Islam Itu Imiah, (Yogyakarta: Laksana, 2018), 217.
} 
Anak perempuan hasil hubungan zina tersebut dihukumi mahram sebab diqiyaskan dengan saudara sepersusuan. Kemahraman saudara sepersusuan dikarenakan adanya aktifitas menyusuinya seorang ibu kepada anak. Sedangkan anak perempuan hasil zina dikarenakan adanya hubungan persetubuhan antara laki-laki dan perempuan. Kemahraman anak perempuan hasil zina diqiyaskan kepada air susu saudara sepersusuan dengan 'illat hukum keduanya sama-sama mengandung sel genetik yang mempengaruhi terhadap kesehatan mental dan fisik anak.

\section{DAFTAR PUSTAKA}

Abbas, Hasjim. Metodologi Penelitian Hukum Islam. Jombang: Program Pascasarjana Studi Hukum Islam Universitas Darul 'Ulum. 2010.

Agama, Departemen. Al-Qur'an dan Terjemahnya. Kudus: Menara Kudus.

Ażiz (Al), Muhammad 'Azzām, 'Abd. al-Qawāid al-Fiqhiyyah. Mesir: Dār al-Hadith, 2005.

Aziz Dahlan, Abdul. Ensiklopedi Hukum Islam. Jakarta: Ichtiar Baru Van Hoeve, 1997.

Bakr 'Abdullah Ibn Muhammad Ibn Abī Shaibah, Abū. al-Musannaf Ibn Abi Shaibah. Beirut: Dār Qurțubah, 2006.

Dāwud, Abì. Sunan Abi dawnd Juz III. t.t: t.p, t.th.

Jaziriy (Al), 'Abd Raḥman. Kitab al-Fiqh 'Alā al-Madæhab al-Arba'ah. Beirut: Dār al-Fikr. t.th

Kompilasi Hukum Islam (KHI) pasal 100.

Mardalis. Metode Penelitian. Jakarta: Bumi Aksara, 2002.

Marzuki, Peter Mahmud. Penelitian Hukum. Jakarta: Kencana, 2010.

Qudamah, Ibn. al-Mughniy Juz VII. Beirut: Dar al Kitab al Arabiy, tt.

Rushd, Ibn. Bidāyah al-Mujtabìd. Beirut: Dār al-Kutub al-'Ilmiyyah, 1988.

Shaghdi (Al), Abū Hasan 'Aliy al-Husain Ibn Muhammad, al-Nitfi fi alFataway Juz. II. Beirut: muassasah al-risalah, t.th.

Sholeh, Qomarudin. Ayat-Ayat Larangan Dan Perintah. Bandung: CV Diponegoro, 2002.

Soekanto, Soerjono. Pengantar Penelitian Hukum. Jakarta: UI-Perss, 2008.

Syarifuddin, Amir. Hukum Perkawinan Islam di Indonesia. Jakarta: Prenada media Group. 2011.

Syukur Al-Azizi, Abdul. Islam Itu Imiah. Yogyakarta: Laksana, 2018.

Uthmān Ibn 'Ali al-Zayla'i, Fakhruddin. Tabyin al-Haqaiq Sharb Kanz alDaqäiq Juz II. Mesir: Mațba'ah al-Kubra, t.th.

UU No. 1 Tahun 1974 Pasal 43 ayat 1 
Yahyā Zakariā Ibn Muhạmmad, Abī. Gāyah al-Wusūul Syarh Lubb al-'Ușūi . Lebanon: Dār al-Kotob al-Ilmiyah, t.th.

Zuhailīy, Waḥbah. Ușūl al-Fiqh al-Islämiy Juz II. Beirut: Dār al-Fikr, 2017. . Al-Fiqh al-Islämìy wa Adillatuh Juг. VII. Beirut: Dār alFikr, 2017. 
